\title{
IMPLEMENTASI KEBIJAKAN PERUBAHAN KEDUDUKAN KELURAHAN DARI PERANGKAT DAERAH MENJADI PERANGKAT KECAMATAN DI KELURAHAN MATAWAI KECAMATAN KOTA WAINGAPU KABUPATEN SUMBA TIMUR PROVINSI NUSA TENGGARA TIMUR
}

\author{
Oleh \\ Umbu Raya Paskah Kulandima ${ }^{1}$, \\ Layla Kurniawati ${ }^{2}$, Etin Indrayani ${ }^{3}$ \\ 1) Institut Pemerintahan Dalam Negeri \\ Program Magister Terapan Studi Pemerintahan Daerah Institut Pemerintahan Dalam Negeri \\ kulandimaumbu@gmail.com \\ ${ }^{2,3)}$ Institut Pemerintahan Dalam Negeri
}

\begin{abstract}
"IMPLEMENTATION OF VILLAGE SELECTION CHANGE POLICY FROM REGIONAL DEVICES INTO DISTRICT DEVICES IN MATAWAI VILLAGE OF WAINGAPU CITY DISTRICT EAST SUMBA REGENCY, EAST NUSA TENGGARA PROVINCE"
\end{abstract}

$T$

is study aims to analyze the implementation of the policy of changing the position of the village from the regional apparatus into the district apparatus in the Matawai Village of Waingapu City, East Sumba Regency, as well as to analyze strategies in overcoming problems arising from the policy.

The analysis in this study uses the theory of policy implementation proposed by George C. Edwards III, namely the analysis of communication approaches, resources, dispositions and bureaucratic structures. Efforts to find solutions using SOAR analysis (Strengths, Opportunity, Aspiration, Result) and using Quantitative Strategic Planning Matrix (QSPM) in determining alternative strategic priorities.

This study uses a descriptive qualitative research method with an inductive approach that aims to find an understanding based on facts or facts that exist at the research location, then a review is carried out in order to obtain a clear and systematic picture in order to solve the problems encountered. Data sources used are person, place, paper. For data and information retrieval is done using interview techniques, documentation, observation, and triangulation. Then the data analysis techniques include data collection, data display, data reduction and conclusion drawing.

Based on the results of research and data processing obtained: 1) In general the implementation of government activities in the Matawai Village went well but there are still problems that arise that concern human resources, budget, authorithy, main tasks and functions, appointment of bureaucrats, incentives and SOP. 2) based on the results of data processing, the alternative strategy chosen as a priority is Matawai Village must optimize the utilization of human resources/staff.

Keywords: policy, changing the position of village

\section{ABSTRAK}

Denelitian ini bertujuan untuk menganalisis implementasi kebijakan perubahan kedudukan kelurahan dari perangkat daerah menjadi perangkat kecamatan di Kelurahan Matawai 
Kecamatan Kota Waingapu Kabupaten Sumba Timur, serta untuk menganalisis strategi dalam mengatasi masalah yang timbul akibat kebijakan tersebut.

Analisis dalam penelitian ini menggunakan teori implementasi kebijakan yang dikemukakan oleh George C. Edwards III, yakni analisis dengan pendekatan komunikasi, sumber daya, disposisi dan struktur birokrasi. Upaya penemuan solusi menggunakan analisis SOAR (strengths, opportunity, aspiration, result) serta menggunakan quantitative strategic planning matriks (QSPM) dalam menentukan alternatif strategi prioritas.

Penelitian ini menggunakan metode penelitian deskriptif kualitatif dengan pendekatan induktif yang bertujuan mencari pemahaman berdasarkan fakta atau kenyataan yang ada di lokasi penelitian, kemudian dilakukan penelaahan agar diperoleh gambaran yang jelas dan sistematis dalam rangka pemecahan masalah yang dihadapi. Sumber data yang digunakan adalah person (orang), place (tempat), paper (data). Untuk pengambilan data dan informasi dilakukan menggunakan teknik wawancara, dokumentasi, observasi, dan triangulasi. Kemudian teknik analisis data meliputi data collection (pengumpulan data), data display (penyajian data), data reduction (reduksi data), dan conclusion drawing (penarikan simpulan).

Berdasarkan hasil penelitian dan pengolahan data diperoleh: 1) Secara umum pelaksanaan kegiatan pemerintahan di Kelurahan Matawai berjalan dengan baik, namun masih terdapat masalah yang timbul, yakni menyangkut sumber daya manusia, anggaran, kewenangan, tugas pokok dan fungsi, pengangkatan birokrat, insentif dan SOP. 2) berdasarkan hasil pengolahan data, alternatif strategi terpilih yang menjadi prioritas adalah Kelurahan Matawai harus mengoptimalkan pemanfaatan sumber daya manusia/staf.

Kata kunci: kebijakan, perubahan kedudukan kelurahan

\section{PENDAHULUAN}

$\mathrm{D}$ engan terjadinya perkembangan dan dinamika kehidupan dalam bidang Pemerintahan khususnya di daerah, serta dalam rangka penguatan sistem desentralisasi dan otonomi daerah, pemerintah mengeluarkan UndangUndang No. 23 Tahun 2014 tentang Pemerintahan Daerah sebagai pengganti Undang-Undang No. 32 Tahun 2004. Kemudian untuk menjalankan undangundang tersebut, pemerintah juga mengeluarkan berbagai peraturan teknis sebagai pedoman pelaksanaannya seperti Peraturan Pemerintah No. 18 Tahun 2016 tentang Perangkat daerah.

Salah satu perubahan yang sangat esensial dalam penyelenggaraan pemerintahan akibat perubahan peraturan tersebut adalah pada kedudukan Kelurahan yang semula sebagai perangkat daerah kini menjadi perangkat Kecamatan. Perubahan tersebut dapat dilihat pada posisi kelurahan yang tidak dimasukkan sebagai unsur perangkat daerah dalam ketentuan Pasal 209 ayat (2) UU 23 Tahun 2014, sementara sebelumnya, yaitu pada Pasal 120 ayat (2) UU 32 Tahun 2004 kelurahan merupakan salah satu unsur perangkat daerah. Selain itu, Pasal 52 ayat (1) PP 18 Tahun 2016 menyatakan kelurahan merupakan perangkat kecamatan yang dibentuk untuk membantu atau melaksanakan sebagian tugas camat. Kelurahan dibentuk dengan peraturan daerah kabupaten/ kota dengan berpedoman pada peraturan pemerintah. Perubahan tersebut kemudian dilakukan pengaturan lebih lanjut dengan dikeluarkannya Peraturan Pemerintah No. 17 Tahun 2018 tentang Kecamatan.

Pasal 25 PP No. 17 Tahun 2018 menyebutkan bahwa kelurahan sebagai perangkat kecamatan mempunyai tugas dan fungsi melaksanakan penyelenggaraan pemerintahan di wilayah Kelurahan yang dipimpin Lurah. Dalam melaksanakan tugas dan fungsi dalam penyelenggaraan pemerintahan di wilayah kelurahan tersebut, lurah dibantu oleh perangkat kelurahan. 
Perubahan nomenklatur kelurahan dari perangkat daerah menjadi perangkat kecamatan berdampak pada tugas pokok dan fungsi kelurahan sebagai organisasi pemerintahan terdekat di masyarakat.

Kelurahan Matawai adalah salah satu kelurahan di Kecamatan Kota Waingapu Kabupaten Sumba Timur Provinsi Nusa Tenggara Timur yang sangat padat penduduknya. Hal ini dapat dilihat dari jumlah penduduk per 31 desember tahun 2019 sebanyak 4.700 jiwa yang terdiri dari 2.406 laki-laki, 2.924 perempuan dan 1.062 kepala keluarga dengan luas wilayah $\pm 2,3 \mathrm{~km}^{2}$. Dilihat dari sisi mata pencarian penduduk yang ada di wilayah Kelurahan Matawai, sebagian besar bermatapencarian sebagai pedagang/wiraswasta, petani, nelayan dan lain sebagainya. Kondisi ini juga didukung dengan adanya pasar umum (Pasar Inpres) dan terminal umum yang menjadi pusat perputaran barang dan jasa di Kota waingapu. Kelurahan Matawai juga merupakan pusat kegiatan pemerintahan yang ada di Kabupaten Sumba Timur karena kantor-kantor pemerintah dan swasta banyak berlokasi di wilayah Kelurahan Matawai.

Kondisi tersebut mengharuskan Kelurahan Matawai untuk sesegera mungkin menyesuaikan kedudukan organisasinya dengan peraturan yang berlaku karena akan sangat banyak kebutuhan masyarakat maupun kebutuhan pemerintahan yang secara aplikatif baru dapat terpenuhi dengan bentuk keorganisasian kelurahan yang baru.

Perubahan kedudukan Kelurahan Matawai menjadi perangkat kecamatan sudah dilaksanakan sejak 2018. Sebagai tindak lanjut terhadap terbitnya Peraturan Pemerintah No. 18 Tahun 2016 tentang Perangkat Daerah serta Peraturan Pemerintah No. 17 Tahun 2018 tentang Kecamatan, Pemerintah Daerah Kabupaten Sumba Timur mengeluarkan Peraturan Daerah Kabupaten Sumba Timur No. 7
Tahun 2016 tentang Pembentukan dan Susunan Perangkat Daerah Kabupaten Sumba Timur yang di dalamnya mengatur perubahan organisasi kelurahan menjadi perangkat kecamatan serta peraturan Bupati Sumba Timur No. 61 Tahun 2016 tentang Kedudukan, Susunan Organisasi, Tugas, Fungsi, dan Tata Kerja Kecamatan di Kabupaten Sumba Timur.

\section{METODE PENELITIAN}

Penelitian ini menggunakan desain penelitian deskriptif kualitatif (qualitative description research) dengan pendekatan induktif yang disesuaikan dengan permasalahan yang akan dibahas, situasi dan kondisi dari lokasi di mana penelitian dilakukan. Tujuan penggunaan desain penelitian deskriptif pada penelitian ini adalah mencari pemahaman makna berdasarkan fakta atau kenyataan yang ada di lokasi penelitian, kemudian dilakukan penelaahan agar diperoleh gambaran yang jelas dan sistematis dalam rangka pemecahan masalah yang dihadapi.

\section{HASIL PENELITIAN DAN PEMBAHASAN}

Perubahan kedudukan Kelurahan dari perangkat daerah menjadi perangkat Kecamatan merupakan amanat dari Undang-Undang No. 23 Tahun 2014 tentang Pemerintahan Daerah sebagaimana dalam Pasal 209 ayat (2) Kelurahan tidak dimasukkan dalam unsur perangkat daerah. Hal ini kemudian ditegaskan oleh Peraturan Pemerintah No. 18 Tahun 2016 yang secara eksplisit dalam Pasal 52 ayat (1) menyebutkan kedudukan Kelurahan sebagai perangkat kecamatan yang dibentuk untuk membantu pelaksanaan sebagian tugas camat.

Kelurahan yang sekarang sebagai perangkat kecamatan berada di bawah naungan camat dan mempunyai tugas untuk membantu camat melaksanakan tugas sesuai dengan ketentuan perundang- 
undangan. Perubahan kedudukan kelurahan ini secara langsung mengurangi fungsi Kelurahan sebagai unit pemerintahan terdepan dalam melayani masyarakat dan organisasi Pemerintahan terdekat di masyarakat. Hal ini dikarenakan Lurah harus bertanggung jawab kepada camat dan tidak memiliki kewenangan penuh yang langsung dilimpahkan dari bupati/wali kota dalam menjalankan kegiatan pemerintahan.

Kedudukan kelurahan sebagai perangkat kecamatan dibentuk untuk membantu dan melaksanakan sebagian tugas camat (Peraturan Pemerintah No. 18 Tahun 2016 tentang Perangkat Daerah Pasal 52 ayat (1)), kemudian Kelurahan dipimpin oleh seorang Kepala Kelurahan yang disebut Lurah selaku perangkat kecamatan dan bertanggung jawab kepada Camat (ayat (3)). Lurah merupakan kepala Kelurahan yang bertanggung jawab kepada Camat, akan tetapi dalam pengangkatannya lurah diangkat oleh bupati/wali kota atas usul Sekretaris Daerah dari pegawai negeri sipil yang memenuhi persyaratan sesuai dengan ketentuan perundang-undangan (pasal 229 ayat (3) Undang-Undang No. 23 Tahun 2014 tentang Pemerintahan Daerah).

Dalam hal pengangkatannya, Lurah dan Camat memiliki kedudukan yang sama, sepertihalnya Lurah yang diangkat oleh bupati/wali kota, Camat selaku Kepala Kecamatan juga diangkat oleh Bupati/Wali kota dalam Undang-Undang No. 23 Tahun 2014 tentang Pemerintah Daerah dalam Pasal 224 ayat (2) "Bupati/Wali kota wajib mengangkat camat dari pegawai negeri sipil yang menguasai pengetahuan teknis pemerintahan dan memenuhi persyaratan kepegawaian sesuai dengan ketentuan peraturan perundang-undangan.

Edwards III mengatakan bahwa di dalam pendekatan studi implementasi kebijakan, pertanyaan abstraknya dimulai dari bagaimana prakondisi untuk suksesnya kebijakan publik dan kedua adalah apa hambatan utama dari kesuksesan kebijakan publik. Untuk menjawab pertanyaan penting itu, maka Edwards III mempertimbangkan empat faktor dalam mengimplementasikan kebijakan publik, yakni communication, resourches, disposition or attitudes, and bureaucratic structure"

Variabel yang sangat menentukan keberhasilan implementasi suatu kebijakan menurut Edwards III sebagaimana disebut di atas dapat dijelaskan sebagai berikut.

Pertama, c o m $m$ u $n$ i c a $t$ i o $n$, berhubungan dengan kejelasan kebijakan atau instruksi hingga ke tingkat pelaksana di lapangan, sehingga mereka dapat memahami dengan jelas apa maksud dan tujuan kebijakan itu dibuat dan bagaimana cara melaksanakannya, dalam hal ini adalah terkait perubahan kedudukan Kelurahan dari perangkat daerah menjadi perangkat Kecamatan di Kelurahan Matawai Kecamatan Kota Waingapu Kabupaten Sumba Timur. Komunikasi menyangkut beberapa hal, yaitu sebagai berikut.

a. Transmition, yaitu berkaitan dengan kemampuan administrator di lapangan dalam mengomunikasikan atau menafsirkan perintah undang-undang terkait perubahan kedudukan Kelurahan dari perangkat daerah menjadi perangkat kecamatan.

b. Clarity, yaitu berkaitan dengan ketersediaan petunjuk teknis pelaksanaan kebijakan implementasi perubahan kedudukan Kelurahan dari perangkat daerah menjadi perangkat Kecamatan di Kelurahan Matawai Kecamatan Kota Waingapu Kabupaten Sumba Timur.

c. Consistency, yaitu berkaitan dengan keberlanjutan serta konsistensi pelaksana di lapangan dalam menjalankan kebijakan perubahan kedudukan Kelurahan dari perangkat daerah menjadi perangkat Kecamatan. 
Kedua, resources, berhubungan dengan ketersediaan sumber daya baik dari segi kuantitas maupun kualitas dalam implementasi kebijakan perubahan kedudukan Kelurahan dari perangkat daerah menjadi perangkat Kecamatan di Kelurahan Matawai Kecamatan Kota Waingapu Kabupaten Sumba Timur. Beberapa aspek penting yang perlu diperhatikan adalah:

a. Staf, yaitu berkaitan dengan apakah jumlah staf pelaksana di lapangan cukup untuk menjalankan kebijakan perubahan kedudukan kelurahan dari perangkat daerah menjadi perangkat Kecamatan di Kelurahan Matawai Kecamatan Kota Waingapu Kabupaten Sumba Timur.

b. Authorithy, yaitu berkaitan dengan sejauh mana para implementor di lapangan memiliki wewenang dalam melaksanakan tugasnya setelah adanya kebijakan perubahan kedudukan kelurahan dari perangkat daerah menjadi perangkat Kecamatan di Kelurahan Matawai Kecamatan Kota Waingapu Kabupaten Sumba Timur.

c. Facilities, yaitu berkaitan dengan ketersediaan daya dukung berupa sarana dan prasarana dalam menunjang implementasi kebijakan perubahan kedudukan kelurahan dari perangkat daerah menjadi perangkat Kecamatan di Kelurahan Matawai Kecamatan Kota Waingapu Kabupaten Sumba Timur.

Ketiga, disposition, berhubungan dengan sikap para pelaksana di lapangan dalam menjalankan berbagai instruksi (instruksi harus jelas) agar tidak terjadi bias-bias dalam proses implementasi kebijakan perubahan kedudukan kelurahan dari perangkat daerah menjadi perangkat Kecamatan di Kelurahan Matawai Kecamatan Kota Waingapu Kabupaten Sumba Timur. Beberapa hal yang perlu diperhatikan dalam kaitannya dengan disposisi yaitu

a. Pengangkatan birokrat, yaitu berhubungan dengan penempatan aparatur pelaksana di lapangan dalam posisi jabatan tertentu yang perlu guna efektivitas implementasi kebijakan perubahan kedudukan kelurahan dari perangkat daerah menjadi perangkat Kecamatan di Kelurahan Matawai Kecamatan Kota Waingapu Kabupaten Sumba Timur.

b. Insentif, yaitu berhubungan dengan apakah implementasi kebijakan perubahan kedudukan kelurahan dari perangkat daerah menjadi perangkat Kecamatan di Kelurahan Matawai Kecamatan Kota Waingapu Kabupaten Sumba Timur diikuti dengan adanya insentif bagi para pelaku di lapangan atau tidak.

Keempat, bureaucratic structure, berhubungan dengan kondisi struktur organisasi instansi pelaksana di lapangan apakah sudah mumpuni atau perlu dilakukan perubahan-perubahan dalam rangka penguatan kapasitas organisasi untuk menyikapi perubahan kedudukan kelurahan dari perangkat daerah menjadi perangkat Kecamatan. Karakteristik yang perlu diperhatikan dalam struktur birokrasi yaitu

a. Standard Operating Procedures (SOP), yaitu berkaitan dengan tahapann prosedur kerja baku dalam kaitannya dengan adanya kebijakan perubahan kedudukan Kelurahan dari perangkat daerah menjadi perangkat kecamatan di Kelurahan Matawai, Kecamatan Kota Waingapu, Kabupaten Sumba Timur.

b. Fragmentation, yaitu berkaitan dengan kekuatan organisasi kelurahan untuk tetap bertahan dalam menyikapi perubahan akibat adanya implementasi kebijakan perubahan kedudukan kelurahan dari perangkat daerah menjadi perangkat kecamatan.

Faktor sumber daya mempunyai peranan penting dalam implementasi kebijakan, karena bagaimanapun jelas dan konsistennya 
ketentuan-ketentuan atau aturan-aturan suatu kebijakan, jika para personel yang bertanggung jawab mengimplementasikan kebijakan kurang mempunyai sumbersumber untuk melakukan pekerjaan secara efektif, maka implementasi kebijakan tersebut tidak akan bisa efektif.

Jika sumber daya yang dimiliki organisasi diartikan sebagai kemampuan organisasi, maka sumber daya pelaksana dipahami sebagai kemampuan pelaksana. Dalam hubungan ini, maka implementasi kebijakan dipengaruhi oleh kemampuan pelaksana yang meliputi kemampuan sumber daya, komitmen, otoritas, koordinasi antar pelaksana dan budaya yang dianut. Implementasi kebijakan tidak dapat dilepaskan dari pelaksananya. Dari sisi pelaksana kebijakan didasarkan pada sumber daya yang dimiliki dengan segala perilakunya. Sumber daya dalam suatu organisasi meliputi kapasitas organisasi dan orang yang terlibat di dalamnya, mutu dan jumlahnya, kewenangan yang dimiliki, dan budaya organisasi. Selain itu, apabila suatu kebijakan dilaksanakan lebih dari satu organisasi maka sumber daya organisasi juga meliputi kerja sama dan koordinasi.

Aspek penting yang perlu diperhatikan pada dimensi sumber daya dalam implemenatsi kebijakan seperti telah diuraikan di atas, yaitu sebagai berikut.

\section{Sumber Daya Manusia}

Sumber daya manusia merupakan kecukupan baik kualitas maupun kuantitas implementor yang dapat melingkupi seluruh kelompok sasaran, sebab tanpa kehandalan implementor, kebijakan menjadi kurang energik dan berjalan lambat. Sedangkan menurut Nawawi, yang dimaksud sumber daya manusia adalah manusia yang bekerja di lingkungan suatu organisasi, disebut juga personel, tenaga kerja, pegawai atau karyawan. Sumber daya manusia di sini dapat digunakan untuk mendukung keberhasilan implementasi kebijakan.
Sumber daya manusia dalam implementasi kebijakan adalah staf. Kegagalan yang sering terjadi dalam implementasi kebijakan salah satunya disebabkan oleh staf/pegawai yang tidak cukup memadai, mencukupi, ataupun tidak kompeten dalam bidangnya. Penambahan jumlah staf dan implementor saja tidak cukup menyelesaikan adanya persoalan implementasi kebijakan, tetapi diperlukan sebuah kecukupan staf dengan keahlian dan kemampuan yang diperlukan (kompeten dan kapabel) di dalam implementasi kebijakan atau melaksanakan tugas yang diinginkan oleh kebijakan itu sendiri.

Selain itu, harus ada ketepatan atau kelayakan antara jumlah stafyang dibutuhkan dan keahlian yang harus dimiliki dengan tugas yang akan dikerjakan, dana untuk membiayai operasionalisasi implementasi kebijakan tersebut, informasi yang relevan dan yang mencukupi tentang bagaimana cara mengimplementasikan suatu kebijakan, dan kerelaan atau kesanggupan dari berbagai pihak yang terlibat dalam implementasi kebijakan tersebut. Hal ini dimaksudkan agar para implementor tidak akan melakukan suatu kesalahan dalam bagaimana caranya mengimplementasikan kebijakan tersebut. Informasi yang demikian ini juga penting untuk menyadarkan orang-orang yang terlibat dalam implementasi, agar di antara mereka mau melaksanakan dan mematuhi apa yang menjadi tugas dan kewajibannya.

Implementasi kebijakan tidak akan berjalan efektif dalam pelaksanaannya bila daya dukung sumber daya kurang, sebagaimana dikemukakan oleh Edwards III, bahwa:

"Implementation orders may be accurately transmitted, clear and consistent, but if implementors lack the resources necessary to carry out policies, Implementation is likely to be ineffective."

Selain itu, ia juga mengemukakan, berikut ini. 
Important resourches include staff of the proper size and with the necessary exprise: relevant and adequate information on how to implement policies and on the compliance of other involved in implementation: the auothority to ensure tha policies are carried out as they are intended, and facilities (including buildings, equipment, land and suppliers) in which or whith which to provide services. Insufficient resourches will mean that laws will not be enforced, services will not be provided, and reasonable regulation will not be developed.

Sumber daya yang penting meliputi staf dalam ukuran yang tepat dengan keahlian yang diperlukan, informasi yang cukup dan relevan tentang cara untuk mengimplementasikan kebijakan dan dalam penyesuaian lainnya yang terlibat di dalam implementasi; kewenangan untuk meyakinkan bahwa kebijakan ini dilakukan semuanya sebagai dimaksudkan; dan berbagai fasilitas (termasuk bangunan, peralatan, tanah dan persediaan) di dalamnya atau dengan memberikan pelayanan. Sumber daya yang tidak cukup akan berarti bahwa undang-undang tidak akan diberlakukan, pelayanan tidak akan diberikan, dan peraturan-peraturan yang layak tidak akan dikembangkan.

Dalam wawancara yang dilakukan penulis bersama sekretaris Lurah Matawai, yakni I Kade Adhi Oka Sujaya, pada Kamis, 23 April 2020 pukul 09.30 WITA, beliau mengatakan bahwa:

"apabila dilihat dari sisi staf tentunya kita membutuhkan jumlah yang lebih banyak (jumlah staf yang ada sekarang masih kurang), ditambah lagi dalam struktur yang baru Sub Bagian Umum menjadi hilang dan terpusat di kecamatan sehingga tugas-tugasnya dibebankan kepada sekretaris. Jumlah staf juga sangat terbatas apabila dibandingkan dengan jumlah penduduk yang harus kami layani, ditambah dengan urusanurusan pemerintahan lainnya, urusan wilayah atau tanah dan lain sebagainya. Juga, seharusnya ada penyegaran staf misalnya berupa mutasi agar pegawai kembali semangat apabila bertemu dengan lingkungan kerja yang baru, sebab kalau kita melihat data, mayoritas pegawai di Kelurahan Matawai sudah bekerja cukup lama sehingga menurut saya sangat perlu ada penyegaran. Selain itu juga staf di Kelurahan ini mayoritas sudah tidak muda lagi sehingga berpengaruh terhadap kecakapan saat bekerja. Dari segi tingkat pendidikan juga harus kita akui bahwa kebanyakan tidak begitu tinggi tingkat pendidikannya, skill mereka juga tidak pernah diasah lagi misalnya melalui program pendidikan dan pelatihan. Aggaran untuk kegiatan seperti itu kan sangat minim, sehingga para staf pun bekerja cukup dengan bermodalkan pengalaman mereka yang bertahun-tahun itu."

Hal ini menjadi kendala dalam pelaksanaan kegiatan pemerintahan di Kelurahan Matawai, Kecamatan Kota Waingapu, Kabupaten Sumba Timur, karena implementasi kebijakan perubahan kedudukan Kelurahan dari perangkat daerah menjadi perangkat Kecamatan tidak disusul dengan pengaturan komposisi staf yang memadai sehingga secara tidak langsung memengaruhi pelaksanaan tugas-tugasnya. Selain itu, penghapusan subbagian umum di Kelurahan pun dinilai kurang tepat karena seharusnya pembagian tugasnya sudah cukup bagus.

Berdasarkan wawancara penulis bersama kepala seksi pemerintahan Kelurahan Matawai, yakni ibu Tamar Pangambang pada Senin, 27 April 2020 pukul 10.15 WITA, beliau mengatakan bahwa:

"dalam melayani masyarakat terkadang kami kewalahan dan mesti lembur karna jumlah masyarakat di wilayah kita sangat 
banyak sementara kami staf jumlahnya sangat terbatas. Kita tau sendiri kondisi masyarakat kita sangat majemuk, adaada saja hal yang mereka lakukan yang membutuhkan peran serta kelurahan, dalam kondisi ini menurut saya memang jumlah kami di kelurahan masing sangat kurang, kita berharap ada tenaga baru yang lebih produktif bisa membantu kami, kami ini kan sudah lumayan dari segi usia jadi kecekatan kami pun sudah tidak seperti anak muda lagi, belum lagi jumlah kami yang sedikit saya kira sangat-sangat berpengaruh terhadap kinerja organisasi Kelurahan Matawai."

Penetapan staf di suatu organisasi mesti berfokus pada kuantitas dan kualitas staf. Kedua hal ini harus seimbang sehingga roda organisasi dapat dijalankan dengan baik. Kekurangan staf dari segi kuantitas akan berpengaruh terhadap efisiensi pelaksanaan tugas serta dapat menimbulkan banyak hal lainnya terbengkalai, sedangkan kekurangan staf dari segi kualitas akan berdampak pada hasil kerja yang kurang optimal dan menurunkan tingkat kepuasan masyarakat.

\section{Sumber Daya Anggaran}

Dalam implementasi kebijakan, anggaran berkaitan dengan kecukupan modal atau investasi atas suatu program atau kebijakan untuk menjamin terlaksananya kebijakan, sebab tanpa dukungan anggaran yang memadai, kebijakan tidak akan berjalan dengan efektif dalam mencapai tujuan dan sasaran.

Dalam wawancara yang dilakukan penulis bersama sekretaris Lurah Matawai, yakni I Kade Adhi Oka Sujaya, pada Kamis, 23 April 2020 pukul 09.30 WITA, beliau mengatakan bahwa:

"kami di kelurahan mengalami kendala dalam proses pencairan dana, ini terkait dengan posisi kelurahan saat ini. Sebagai perangkat daerah, anggaran dari APBD langsung dicairkan ke Kelurahan, sedangkan dalam posisi sebagai perangkat Kecamatan, kini proses pencairannya harus melalui kecamatan. Ini tentunya menjadikan anggaran memiliki rentang waktu yang lebih lama hingga tiba di kelurahan, sehingga proses kegiatan pemerintahan pun terlambat. Hal ini paling sering terjadi pada awal tahun anggaran, bahkan sampai tertunda dua hingga tiga bulan."

Anggaran memang merupakan hal yang mutlak dibutuhkan. Roda dalam suatu organisasi baik pemerintahan maupun swasta hampir spenuhnya digerakkan oleh anggaran di luar faktor-faktor pendukung yang lain seperti staf maupun sarana prasarana. Tidak hanya dalam hal kekurangan atau ketidaktersediaan anggaran, tetapi hal keterlambatan anggaran juga berpengaruh sangat besar terhadap efektivitas dan efisiensi pelaksanaan tugas dari pada organisasi.

\section{Wewenang (Authorithy)}

Sumber daya lain yang cukup penting dalam menentukan keberhasilan suatu implementasi kebijakan adalah kewenangan. Edwards III dalam Widodo menyatakan bahwa:

Kewenangan (authorithy) yang cukup untuk membuat keputusan sendiri yang dimiliki oleh suatu lembaga akan memengaruhi lembaga itu dalam melaksanakan suatu kebijakan. Kewenangan ini menjadi penting ketika mereka dihadapkan suatu masalah dan mengharuskan untuk segera diselesaikan dengan suatu keputusan.

Pada umumnya kewenangan harus bersifat formal agar perintah dapat dilaksanakan secara efektif. Maka kewenangan merupakan otoritas atau legitimasi bagi semua pelaksana dalam melaksanakan kebijakan yang ditetapkan. Ketika wewenang tidak nihil, maka kekuatan para implementor di mata 
publik tidak terlegitimasi, sehingga dapat juga menggagalkan proses implementasi kebijakan publik.

Konsekuensi terhadap bunyi Pasal 2 ayat (2) Peraturan Bupati Sumba Timur No. 61 Tahun 2016 tentang Kedudukan, Susunan Organisasi, Tugas, Fungsi dan Tata Kerja Kecamatan di Kabupaten Sumba Timur yang menyatakan bahwa "kelurahan merupakan perangkat kecamatan yang dibentuk untuk membantu atau melaksanakan sebagian tugas camat" adalah hilangnya kewenangan yang dimiliki oleh kelurahan dalam membuat kebijakan yang bersifat strategis sebagai inovasi, permasalahannya adalah karena kini kelurahan tidak lagi memiliki wewenang dalam menyusun renstra. Rencana strategis kelurahan harus disesuaikan dengan kebutuhan kecamatan, hal ini menyebabkan sejumlah hasil musrenbang kelurahan dihapus dalam musrenbang tingkat kecamatan karena dinilai tidak sesuai dengan tujuan kebijakan kecamatan, padahal secara independen institusi kelurahan sangat membutuhkan program-program tersebut, seperti pengadaan motor sampah dan pembangunan tembok penahan longsor, sebab fungsi kontrol terhadap pelaksanaan kebijakan sepenuhnya berada dalam kewenangan Kecamatan.

Dalam wawancara yang dilakukan penulis bersama sekretaris Lurah Matawai, yakni I Kade Adhi Oka Sujaya, pada Kamis, 23 April 2020 pukul 09.30 WITA, beliau mengatakan bahwa:

"kalau dari segi kewenangan memang ada beberapa kewenangan kelurahan yang menjadi hilang atau beralih ke kecamatan, kewenangan tersebut menurut kami cukup substansial. Kewenangan tersebut, yaitu yang pertama adalah bahwa Kelurahan Matawai dengan adanya perubahan kedudukan menjadi perangkat Kecamatan kini tidak lagi memiliki kewenangan untuk menyusun renstra kelurahan, kami mau tidak mau harus menyesuaikan dengan apa yang menjadi program dari kecamatan, sementara kita tahu bersama bahwa kelurahan merupakan ujung tombak pemerintahan selain desa yang memiliki akses paling dekat dengan masyarakat sehingga secara otomatis lebih mengetahui kebutuhannya masyarakat pada wilayah administratifnya. Kemudian yang kedua misalnya kewenangan pencairan anggaran sebelum sampai ke kelurahan harus melalui kecamatan terlebih dahulu, sementara sebagai perangkat daerah anggaran kelurahan langsung ke khas kelurahan, alurnya lebih sederhana. Kendala seperti ini biasanya terjadi masalah pada masa-masa awal tahun anggaran, yaitu terlambatnya kegiatan kemasyarakatan bahkan beberapa kegiatan rutin harus ditunda karena keterlambatan pencairan anggaran. Yang ketiga adalah bahwa kelurahan tidak bebas lagi secara inovatif mengambil atau melaksanakan berbagai tindakan ataupun kegiatan yang bersifat strategis, karena selalu mengharuskan adanya koordinasi terlebih dahulu dengan pihak kecamatan dalam hai ini camat sebagai pejabat yang memiliki tanggung jawab dalam memberikan laporan kepada bupati melalui sekretaris daerah."

Sebagai sebuah institusi yang sangat dekat dengan masyarakat, tentunya kelurahan diperhadapkan dengan berbagai persoalan sosial dan administrasi yang lebih kompleks, sehingga membutuhkan kewenangan yang khusus seperti pada saat kelurahan masih sebagai perangkat daerah. Namun, pasca implementasi perubahan kedudukan kelurahan dari perangkat daerah menjadi perangkat kecamatan, mau tidak mau kelurahan harus berupaya untuk bergerak sesuai dengan ketentuan yang berlaku saat ini meskipun dengan kewenangan yang terbatas. 
Hal ini senada dengan yang disampaikan oleh Julianus Abraham Koli, selaku kepala bagian tata pemerintahan saat wawancara pada Selasa, 21 April 2020 pukul 10.00 WITA, beliau mengatakan bahwa:

"memang betul bahwa berdasarkan ketentuan yang baru ada beberapa kewenangan kelurahan yang hilang dan berpindah ke kecamatan, misalnya kelurahan tidak lagi berhak menyusun renstra sendiri, harus terintegrasi ke kecamatan, kemudian tugas-tugas organisasi yang lainnya juga berpindah mengikuti SOTK yang baru."

Kewenangan merupakan dasar untuk bertindak, berbuat dan melakukan kegiatan atau aktivitas dalam sebuah organisasi, tanpa wewenang, unsur-unsur dalam organisasi tidak dapat melakukan apa-apa. Demikian juga dengan organisasi kelurahan, tanpa adanya kewenangan penyusunan renstra dan berbagai kewenangan lainnya maka kelurahan tidak bisa berbuat apa-apa selain patuh dan tunduk terhadap si pemilik kewenangan dalam hal ini adalah kecamatan.

\section{Fasilitas (Facility)}

Edwards III menyatakan bahwa fasilitas merupakan sarana yang digunakan untuk operasionalisasi implementasi suatu kebijakan yang meliputi gedung,tanah, dan berbagai sarana lainnya yang akan memudahkan dalam memberikan pelayanan dalam implementasi kebijakan:

Physical facilities may also be critical resources in implementation. An implementor may understand what he suppose to do, may have authorithy to exercise his task, but without the necessary building, equipment, suppliers, and even green space implementation will not succeed.

Fasilitas fisik merupakan faktor penting dalam implementasi kebijakan. Implementor mungkin memiliki staf yang mencukupi, mengerti apa yang harus dilakukannya, dan memiliki wewenang untuk melaksanakan tugasnya, tetapi tanpa adanya fasilitas pendukung (sarana dan prasarana) maka implementasi kebijakan tersebut tidak akan berhasil.

Pada implementasi kebijakan perubahan kedudukan kelurahan dari perangkat daerah menjadi perangkat kecamatan di Kelurahan Matawai tidak ada penambahan ataupun pengurangan fasilitas dari semenjak diberlakukannya kebijakan itu.

Dalam wawancara yang dilakukan penulis bersama kepala seksi pemerintahan Kelurahan Matawai, Tamar Pangambang, pada Senin, 27 April 2020 pukul 10.15 WITA, beliau mengatakan bahwa:

"kalau untuk fasilitas memang sejujurnya masih banyakyangkurang, namun sejauh ini Kelurahan Matawai sudah terbiasa bekerja dengan fasilitas yang ada. Apa yang ada itulah yang kita maksimalkan fungsinya dan kalau ada hal-hal lain yang memang harus diadakan kami selalu berupaya menemukan alternatif solusi. Yang terpenting bagi kami adalah fasilitas-fasilitas yang dibutuhkan dalam pelayanan dasar masyarakat seperti kertas guna keperluan administrasi bisa terpenuhi, kalau fasilitas pendukung lainnya kita sesuaikan dengan kondisi saat ini saja."

Kebutuhan akan ketersediaan fasilitas kelurahan pada prinsipnya sangat diharapkan karena tentu dapat menunjang optimalisasi pelaksanaan tugas-tugas kepemerintahan, namun dengan kondisi riil di lapangan mengharuskan semua aparat kelurahan lebih inovatif berpikir dalam rangka menyiasati keterbatasan yang terjadi.

Dalam wawancara bersama Matias Sedu selaku warga masyarakat pada Kamis, 23 April 2020 pukul 15.00 WITA, beliau mengatakan:

"untuk membantu masyarakat buang sampah saja kelurahan hanya memiliki 
dua buah motor sampah sementara wilayah kita luas, kami kadang harus menunggu berhari-hari baru bisa sampahnya terkondisikan, jadi intinya fasilitas yang dimiliki kelurahan masing sangat kurang, belum lagi kalau kita ke kantor dari dulu sampai sekarang kayaknya begitu-begitu saja tidak ada yang bertambah."

Fasilitas merupakan hal yang sangat mencolok apabila dalam suatu organisasi pemerintahan yang bersentuhan langsung dengan masyarakat terjadi kekurangan karna secara fisik dapat disaksikan langsung oleh masyarakat sekitar dan manfaatnya pun dapat terasa secara langsung, sehingga memang kecukupan ketersediaan fasilitas dalam Kelurahan Matawai sangat dibutuhkan dalam rangka menunjang fungsi pelayanan kepada masyarakat.

Salahsatualternatifyangdapatdigunakan sebagai landasan guna menemukan solusi terbaik dari berbagai persoalan tersebut di atas adalah dengan melakukan analisis menggunakan metode SOAR. Dalam analisis SOAR akan diidentifikasi apa yang menjadi kekuatan, peluang, aspirasi dan hasil yang diharapkan sehingga dapat dirumuskan strategi yang tepat. Faktor-faktor tersebut dijelaskan sebagai berikut.

Faktor kekuatan (strengths) dalam implementasi kebijakan perubahan kedudukan kelurahan dari perangkat daerah menjadi perangkat kecamatan di Kelurahan Matawai, Kecamatan Kota Waingapu, Kabupaten Sumba Timur yaitu tidak ada penolakan dari para staf terhadap kebijakan tersebut; adanya Peraturan PerundangUndangan yang menjadi payung hukum, yaitu Undang-Undang No. 23 Tahun 2014 tentang Pemerintahan Daerah, Peraturan Pemerintah No. 18 Tahun 2016 tentang Perangkat Daerah, Peraturan Pemerintah No. 17 Tahun 2018 tentang Kecamatan, Peraturan Daerah Kabupaten Sumba Timur No. 7 Tahun 2016 tentang Pembentukan dan Susunan Perangkat Daerah Kabupaten Sumba Timur dan Peraturan Bupati Sumba Timur No.61 Tahun2016tentang Kedudukan, Susunan Organisasi, Tugas, Fungsi dan Tata Kerja Kecamatan di Kabupaten Sumba timur. Dengan adanya berbagai peraturan tersebut, maka Pemerintah Daerah Kabupaten Sumba Timur dan Kelurahan Matawai serta Kecamatan Kota Waingapu memiliki dasar yang sangat kuat dan jelas dalam melaksanakan kebijakan perubahan kedudukan; Memiliki pertimbangan yang matang dan masukan dari lebih banyak buah pemikiran; Prestasi kerja pegawai dapat dinilai secara lebih hierarkis; Orientasi kebutuhan terhadap permintaan pengadaan fasilitas lebih bagus; mendorong terciptanya upaya optimalisasi sumber daya; Orientasi kerja pegawai terletak pada keberhasilan organisasi; Mendorong tersedianya standarstandar pelayanan minimal.

Faktor peluang (opportunity) dalam implementasi kebijakan perubahan kedudukan kelurahan dari perangkat daerah menjadi perangkat kecamatan di Kelurahan Matawai, Kecamatan Kota Waingapu, Kabupaten Sumba Timur yaitu terjadi perampingan organisasi; Pengawasan terhadap penggunaan anggaran menjadi lebih ketat; Kebijakan yang dihasilkan lebih luas dan lebih menyeluruh; Data base kepegawaian terpusat dan lebih mudah dihimpun; Optimalisasi dan pemeliharaan yang lebih baik terhadap sarana prasarana yang telah tersedia; Kelurahan lebih kritis dan kreatif dalam menyusun rencana kerja; terjadi efisiensi penggunaan anggaran; serta pengaduan dapat dilakukan oleh masyarakat pada level birokrasi yang lebih tinggi.

Faktor aspirasi (aspiration) dalam implementasi kebijakan perubahan kedudukan kelurahan dari perangkat daerah menjadi perangkat kecamatan di Kelurahan Matawai, Kecamatan Kota Waingapu, Kabupaten Sumba Timur yaitu Penempatan staf harus lebih proporsional; diperlukan upaya-upaya penyederhanaan proses 
pencairan anggaran; Memberi ruang bagi kelurahan untuk hal yang bersifat inovatif; Pemanfaatan teknologi dalam pengelolaan data; Pemerintah perlu memperhatikan keseimbangan antara fasilitas yang dibutuhkan dengan kondisi pemerintahan, sosial dan ekonomi serta geografis Kelurahan Matawai; Harus ada penambahan jumlah staf dan kegiatan pendidikan dan pelatihan; Perlu adanya pemberian insentif melalui pos kegiatan yang lain; Menyediakan SOP yang jelas dan sederhana.

Faktor hasil (result) yang menjadi harapan dalam implementasi kebijakan perubahan kedudukan kelurahan dari perangkat daerah menjadi perangkat kecamatan di Kelurahan Matawai, Kecamatan Kota Waingapu, Kabupaten Sumba Timur yaitu Terciptanya efektivitas dan efisiensi organisasi; Efektivitas dan efisiensi penggunaan anggaran; Menghasilkan kebijakan strategis yang pro rakyat; Administrasi lebih terpusat, update dan terdigitalisasi; Efisiensi penggunaan fasilitas; Efektivitas pemanfaatan personel; Peningkatan motivasi kerja pegawai; dan pelayanan yang dekat dengan masyarakat.

Berdasarkan strategi analisis SOAR, peneliti mencoba merumuskan strategi alternatif yang dapat dilakukan Kelurahan Matawai untuk mengatasi masalah yang timbul dalam implementasi kebijakan perubahan kedudukan kelurahan dari perangkat daerah menjadi perangkat kecamatan di Kelurahan Matawai, Kecamatan Kota Waingapu, Kabupaten Sumba Timur. Strategi alternatif tersebut di antaranya adalah: Kelurahan perlu mengusulkan mutasi pegawai yang disusun secara baik sesuai kompetensi; Formasi dan jumlah pegawai di kelurahan harus ditambah hingga seimbang dengan jumlah masyarakat yang harus dilayani; Kebijakan dijalankan sepenuhnya berdasarkan peraturan yang ada; serta perlu melakukan sosialisasi terhadap struktur organisasi yang baru kepada masyarakat.
Setelah diperoleh alternatif strategi yang dihasilkan dari analisis SOAR, maka selanjutnya adalah pemilihan strategi yang terbaik. Adapun alat analisis yang digunakan adalah Matriks Perencanaan Strategi Kuantitatif/QSPM (Quantitative Strategic Planning Matrix).

QSPM merupakan teknik yang menunjukkan strategi alternatif mana yang paling baik untuk dipilih. QSPM adalah alat yang direkomendasikan bagiparaahlistrategi untuk melakukan evaluasi pilihan strategi alternatif secara objektif berdasarkan key success factor internal-eksternal yang telah diidentifikasikan sebelumnya.

Hasil olahan data menggunakan matriks QSPM, terdapat satu alternatif strategi terpilih yang diprioritaskan untuk diterapkan oleh Kelurahan Matawai, yaitu Kelurahan perlu menambah skill dari staf yang ada melalui kegiatan diklat, Kelurahan perlu mengusulkan penambahan jumlah staf melalui penyusunan rencana kerja, Kelurahan perlu memaksimalkan kapasitas personel yang ada melalui pembagian habis tugas yang merata, rencana kerja harus dibuat lebih matang dan dilakukan oleh staf yang dianggap mampu.

\section{SIMPULAN DAN SARAN}

Implementasi kebijakan perubahan kedudukan kelurahan dari perangkat daerah menjadi perangkat kecamatan di Kelurahan Matawai, Kecamatan Kota Waingapu, Kabupaten Sumba Timuryang sudah berjalan dengan baik harus dapat dilaksanakan secara terus menerus dan secara konsisten dapat dipertahankan terutama bagi para implementor di lapangan.

Kelurahan perlu menerapkan alternatif strategi yang telah diuraikan pada hasil penelitian ini dalam mengatasi permasalahan yang ada sebagai dampak dari implementasi kebijakan perubahan kedudukan kelurahan dari perangkat daerah menjadi perangkat kecamatan. 


\section{DAFTAR RUJUKAN}

Agustino, Leo. 2012. Dasar-Dasar Kebijakan Publik. Jakarta: Alfabeta.

Anderson. 2004. Public Policy Making. USA: Second Edition, I Lotfilin Company. Adi

Arikunto, Suharsimi. 2013. Prosedur Penelitian: Suatu Pendekatan Praktik. Jakarta: Rineka Cipata.

Bromley, Daniel W., 1989, Economic Interest and Institutions: The Conceptual Foundations of Public Policy. New York: Basil Blackwell Ltd

Budiarjo, Miriam. 2008. Dasar-Dasar Ilmu Politik. Jakarta: Gramedia Pustaka.

Bungin, Burhan.2011. Penelitian Kualitatif. Indonesia: Prenada Media Group.

Creswell, John W.2014. Research Design Qualitative, and Mixed Methods Approaches. Inc. California: Sage Publications.

Darfison. 2016. Soar Analysis. Retrieved Maret 2018. From Darfison. https: //indconsult. blogspot.id

David, Fred S. 2009. Manajemen Strategis Konsep, Edisi 12. Jakarta: Salemba Empat

Edwards III, George C. 1980. Implementing Public Policy. Washington, DC: Conggressional Quarterly Press.

Grindle, M. 1980. Politics and Policy implementation, in The Third World, New Jersey: Priceton University Press. Hlm.6. 2006. Politics and Policy Implementation in the Third World. Sumber: https: //www. ebookspdf. org/download/buku-grindle.html.

Miles, M.B, Huberman, A.M, and Saldana, J. 2014. Qualitative Data Analysis, A Methods Sourcebook, Edition 3. USA: Sage Publications.
Moleong J.Lexy. 2011. Metode Penelitian Kualitatif. Bandung: Rosda.

Nazir, M. 2013. Metode Penelitian. Bogor: Ghalia.

Nugroho, D, Riant. 2003. Kebijakan Publik: Formulasi, Implementasi, dan Evaluasi. Jakarta: PT Elex Media Komputindo

Patilima, Hamid. 2013. Metode Penelitian Kualitatif. Bandung: CV, Alfabeta

Rahyunir, Rauf. 2016. Posisi Dewan Perwakilan Rakyat Daerah dalam Pemerintahan Daerah. Pekanbaru: Marpoyan Tujuh.

Robbins, Stephen P, 1994. (Dalam Saragi) Teori Organisasi, Struktur, Desain dan Aplikasi. Jakarta: Arcan

Siagian, Sondang P. 2007. Organisasi, Kepemimpinan dan Perilaku Administrasi. Jakarta: PT Gunung Agung

Sugiyono. 2018. Metode Penelitian Kuantitatif Kualitatif dan R\&D. Bandung: Alfabeta

Tachjan, H. 2006. Implementasi Kebijakan Publik. Bandung: AIPI

Van Meter, Donald S. And Van Horn, Carl E. 1975.“ The Policy Implementation Process. A Conceptual Framework". Administration and Society, Vol.6 No. 4. London: Sage Publications, Inc.

Wasistiono, Sadu, Ismail Nurdin \& M. Fahrurozi. 2009. Perkembangan Organisasi Kecamatan dari Masa ke Masa. Bandung: Fokusmedia

Winardi. I. S. 2005. Motivasi dan Pemotivasian dalam Manajemen. Jakarta: PT Raja Grafindo Pustaka 
Virioner - Vol. $13 \backslash$ No. $2 \backslash$ Agustus 2021 